\title{
Lutheran Theological Education in an Ecumenical and Multicultural Setting: Public Use of Archives and Perceptions at the Lutheran Theological Institution (LTI) Library, Pietermaritzburg, South Africa
}

\author{
FRANCIS GARABA, PH.D. \\ Senior Lecturer, University of Fort Hare, Department of Library \& Information Science Alice (Main campus), \\ King Williams Town, Alice 5700, South Africa \\ e-mail: fgaraba@ufh.ac.za
}

Lutheran Theological Education in an Ecumenical and Multicultural Setting: Public Use of Archives and Perceptions at the Lutheran Theological Institution (LTI) Library, Pietermaritzburg, South Africa

\section{ABSTRACT}

This paper reports on the findings of a study that was carried out in 2014 at the Lutheran Theological Institute (LTI) Library on public use of archives and user perceptions about archives in the library. Archival registration data in the form of user statics, library membership statistics, annual reports and a questionnaire were the primary sources of data. The study established that users were generally aware of what archives are, that the most consulted archival material were church and diocese minutes and that amongst the recommended strategies to promote visibility for the archives were exhibitions, guided tours, publications, an open day on archives and the establishment of a friends of the archives group.

Key words: Exhibitions, publications, outreach, ICA Archives Day, LTI Library

Formazione teologica luterana in un contesto ecumenico e multiculturale: uso pubblico degli archivi e percezioni presso la Biblioteca dell'Istituto Teologico Luterano (LTI), di Pietermaritzburg, Sud Africa

\section{SINTESI}

Il presente articolo relaziona sui risultati di uno studio condotto nel 2014 presso la Biblioteca dell'Istituto Teologico luterano (LTI) sull'uso pubblico degli archivi e delle impressioni degli utenti sugli archivi nella biblioteca. I dati di registrazione d'archivio in forma di statica degli utenti, le statistiche delle iscrizioni alla biblioteca, le relazioni annuali e un questionario sono state le fonti primarie dei dati. Lo studio ha dimostrato che in genere gli utenti sono stati consapevoli di ciò che sono gli archivi, che i materiali d'archivio più consultati sono stati le minute riguardante la chiesa e le diocesi, e che tra le strategie consigliate per promuovere la visibilità degli archivi sono state mostre, visite guidate, pubblicazioni, un open day negli archivi e l'istituzione di un gruppo di amici degli archivi.

Parole chiave: mostre, pubblicazioni, raggio d'azione, Giornata degli Archivi dell'ICA, Biblioteca LTI

Luteransko teološko izobraževanje $\mathrm{v}$ ekumenskem in večkulturnem okolju: javna uporaba arhivskega gradiva ter percepcije v knjižnici Luteranske teološke institucij (LTI) v Pietermaritzburgu, Južna Afrika

\section{IZVLE $\check{C} E K$}

Članek poroča o ugotovitvah študije, ki je bila izvedena leta 2014 v knjižnici luteranskega teološkega inštituta (LTI) glede javne uporabe arhivskega gradiva in percepcij uporabnikov o arhivskem gradivu v knjižnici. Kot primarni viri podatkov so bile za analizo uporabljene arhivske uporabniške statike, knjižnične statistike članstva, letna poročila in vprašalniki. Študija je ugotovila, da se uporabniki na splošno zavedajo, kaj arhivi so. Najbolj uporabljeno gradivo so bili cerkveni in škofijski zapisniki. Kot priporočene strategije za spodbujanje prepoznavnosti so bile navedene arhivske razstave, vodeni ogledi, publikacije, dan odprtih vrat o arhivih in vzpostavitev skupine prijateljev arhiva.

Ključne besede: razstave, publikacije, promocija, mednarodni arhivski dan, knjižnica Luteranske teološke institucije 
Francis GARABA: Lutheran Theological Education in an Ecumenical and Multicultural Setting: Public Use of Archives and Perceptions at the Lutheran Theological Institution (LTI) Library..., 215-224

\section{Introduction}

Outreach remains one of the fundamental responsibilities of an archivist. Millar (2010) pointed out that outreach is not just about making archival materials available but also involves raising awareness of the existence of the archival repository and the nature of its holdings and services. The need for archivists to take the lead in promoting awareness and appreciation of archives as advocated by Millar (2010) reaffirms why this task is so sacrosanct to the profession and was one of the drivers of this study. Outreach refers to that group of activities that are designed to raise the profile of the archives thereby promoting its visibility and use of archives.

An assortment of terms has been used to refer to those activities in which the archival institution seeks user response to its services or in its bid to raise the profile of the organization either internally or externally. Educational programmes, external programmes, advocacy, developmental services, public programming and public service are other synonyms used as substitutes for the broad term "outreach". Outreach has been defined as those activities whereby archival institutions ensure responsiveness to users, secure user participation and promote the use of archives (Harris, 2000, p. 26). Outreach is an extension of reference work and, as Roe $(1988, p .218)$ highlighted, while the purpose of archives is to preserve and make available historical resources, that goal lacks substance if the resources remain unused. This view has been shared by Harris (2000, p. 26; see also Pederson, 1983, p. 306; Freeman, 1984, p. 282; Blais and Ennes, 1990-91, p. 107; Mnjama, 2009) who stated that public programming is arguably the clearest manifestation of archivists having embraced the notion that use is indeed the ultimate goal of all their endeavours.

Pederson (2008) observed that outreach is about relationships with people, with influencing people to change their attitudes and behaviours. In the same vein, Theimer $(2014, p .146)$ argues that reframing our mission entails not only focusing on our collections but on our constituencies, the people that is. Ericson (1990-91) also noted that opening up the holdings of an archival institution generates their increased usage and he stated that:

“... if, after we brilliantly and meticulously appraise, arrange and describe archives and nobody comes to use them, then we have wasted our time.

Hunter $(2003$, p. 229) pointed out that one of the frustrating things for an archivist is to know that the collections have great research value, but that they are underutilized. In fact, information gains value when utilized (Ngulube, 1999, p. 19) hence this paper therefore attempted to establish inter alia whether there was awareness by users on what archives are, their importance, public usage, if any, in their quest for knowledge. This focus dovetails with the IIAS 2016 conference theme: Using archives: public use (exhibitions, publications, conferences).

\section{Contextual setting}

The Lutheran Theological Institute (LTI) is owned by a Trust, the South African Lutheran Theological Training Trust (SALTTT) which is a common venture of the Evangelical Lutheran Church in Southern Africa (ELCSA) and the United Evangelical Lutheran Church in Southern Africa (UELCSA). The LTI is linked to the School of Religion, Philosophy \& Classics (SRPC) at the University of KwaZulu-Natal, Pietermaritzburg. The mission of the LTI is to train men and women for leadership, ministry and service. The LTI Library is endowed with primary and secondary material from its consolidated former institutions that is Umphumulo Lutheran Theological Seminary, the Marang Lutheran Theological Seminary and the Lutheran House of Studies.

The LTI library is a member of the Cluster of Theological Institutions ${ }^{1}$. These institutions inter alia share library and staff resources. Students come from South Africa and from various African countries and other parts of the world. Averagely, the annual library membership is around 140+- registered

\footnotetext{
1. The Pietermaritzburg Cluster of Theological Libraries (PCTL) is an association of the libraries of the Evangelical Seminary of Southern Africa (ESSA), St. Joseph's Theological Institute (SJTI), Cedara, the School of Religion, Philosophy and Classics (SRPC), University of KwaZulu-Natal, the Congregational House of Formation (CHoF), Anglican House of Studies (AnHoS), Seith Mokitimi Methodist Seminary (SMSS) and the Lutheran Theological Institute (LTI). It is in essence an agreement among the theological institutions in the area to form a consortium of theological educational institutions to work together towards the provision of a contextual theological education (Van Rooyen, 1996).
} 
users and this is made mostly of diploma, ministerial, undergraduate, postgraduate students, staff and retired members of the Lutheran Church.

Within the institute, there is archival repository that serves as an adjunct to the theological library thereby serving as a rich resource of primary material on the history of the Lutheran Church in South Africa. At the LTI Archives documents relating to individual staff members, students, pastors, and their papers and research, as well as to institutions, associations, curricula, conferences, student bodies, applications, welfare etc, minutes of meetings, reports, societies, committees, records of appeal and adjudication, interoffice memos, appointment books, registers, charters, constitutions and bylaws, legal papers, deeds, articles of incorporation, agreements, financial ledgers, and various other papers pertaining to the different churches or missions are included in the files. In addition, the archival repository also maintains a historical depository of denominational journals, periodicals, convention proceedings or transactions pertaining to the Lutheran Church in South Africa (Garaba and Zaverdinos, 2014).

\section{Justification of the study}

Access and utilization of archives were deemed fundamental to this study for the simple reason that collections that remain sequestrated from the public serve no purpose. Apparently, use remains the ultimate goal of all archival endeavor (Harris, 2000). The aim was to establish whether there is awareness by users on what archives are, their importance, usage, if any, in their quest for knowledge and their suggestions on how best to raise the profile of the archives with regard to publicity. In a nutshell, this was an attempt to assess the breadth of our potential constituency

\section{Problem statement}

Access to and utilization of archives is a fundamental human right. However in many archival repositories, access and usage of archives is significantly low simply because the importance of archives and their use is relatively unknown. This is because the identity or image crisis tag that has haunted the profession since time immemorial has proven difficult to eradicate. The International Archives Day (2014) observed that the public's image of the archives is foggy: often confused with libraries, archives continue to be perceived as documents for internal use only, which are difficult to access and are of interest only to historians. The perception of records and archives by the public and the organizations that create them is not clear.

User studies remain fundamental in determining the needs of clients and to enable archivists to effectively relate to the public (Ngoepe and Ngulube, 2011). Duff and Cherry $(2008, p$. 499) concurred and stated that archivists have begun to conduct more formal evaluation studies to ensure their services and systems meet users' needs. Consequently, this research was thus borne out of the need to assess archival awareness and consultation, and identify strategies peculiar with users to raise the profile of archives.

\section{Research purpose and objectives of the study}

The general purpose of this study was on access to religious archives in the LTI library with the primary aim of trying to establish whether there was awareness on what archives are, their importance, usage, if any, in users' quest for knowledge and identify their preferences on how best to raise the profile of the archives with regard to publicity. The specific focus areas were as follows:

1. Establish the users' understanding of archives and identify frequently consulted material;

2. Determine awareness about the existence of an LTI Archives brochure in the library; and

3. Identify popular strategies recommended by users that the library should adopt to raise the profile of archives.

The forgoing objectives will be the focus of this paper as these resonate with the theme of the IIAS conference: Using archives: public use (exhibitions, publications, conferences). 
Francis GARABA: Lutheran Theological Education in an Ecumenical and Multicultural Setting: Public Use of Archives and Perceptions at the Lutheran Theological Institution (LTI) Library..., 215-224

\section{The research story}

This was case study research that employed the use of archival registration data and a questionnaire to collect quantitative data. The 9th of June of each year is internationally recognized as Archives Day by the International Council on Archives (ICA) and the LTI Archives mounted an exhibition inside the library of its archives and other memorabilia for the whole month of June 2014 (Refer to Appendix 1). During the course of this promotional display, viewers were handed a questionnaire for completion in attempts to assess their general understanding of archives. Enclosed in the questionnaire was a poem on religious archives as a token of appreciation for them participating in this exercise and as a form of advertisement (Refer to Appendix 2). The number of users recorded in our daily register who visited the stand during this month was 35 and each was a given a questionnaire for completion during their own spare time. A total of 29 questionnaires were returned by users which represented a response rate of $83 \%$.

\section{Research findings}

At the LTI Archives, whilst administrative statistics on the number of users consulting the archives shows a 27\% increase between the years 2012 and 2014 much can be done to improve usage considering the annual membership for the library as illustrated in Table 1. The average annual membership at LTI is around 140.

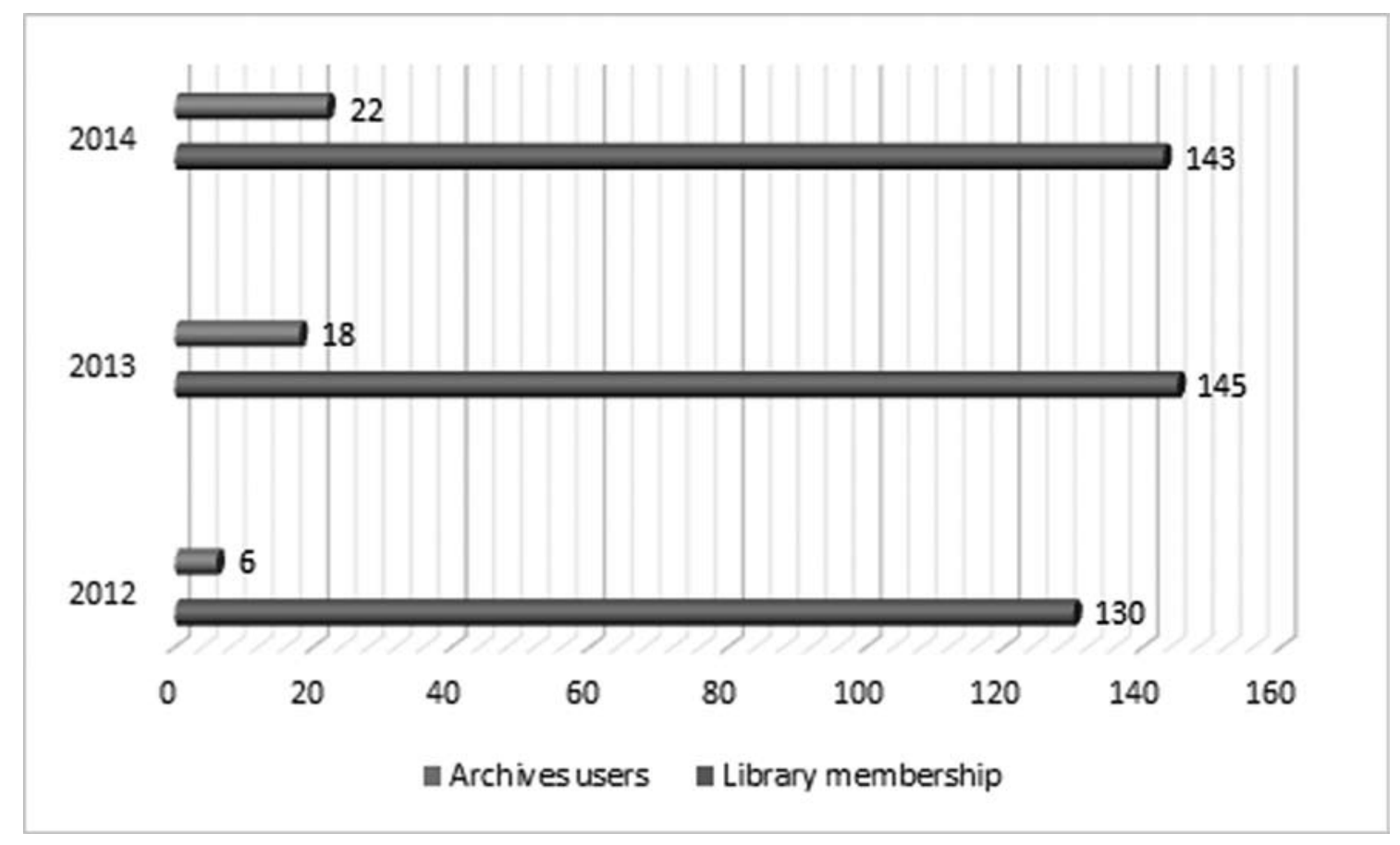

Image 1: Users of archives at LTI Library 2012-2014

The findings here are reported according to the following objectives: users' understanding of archives and frequently consulted material awareness about the existence of an LTI brochure and on some of the popular strategies that users recommended in an effort to raise awareness about archives.

\section{Establish the users' understanding of archives and identify frequently consulted material}

Library users at the LTI were generally aware of what archives are as $18(62 \%)$ of the answers were in the affirmative compared to $11(32 \%)$ who were unaware as shown in Figure 2. The archival material largely familiar with users were minutes, diocese and church council minutes that is as shown in Figure 3 and these were the frequently consulted as well. 


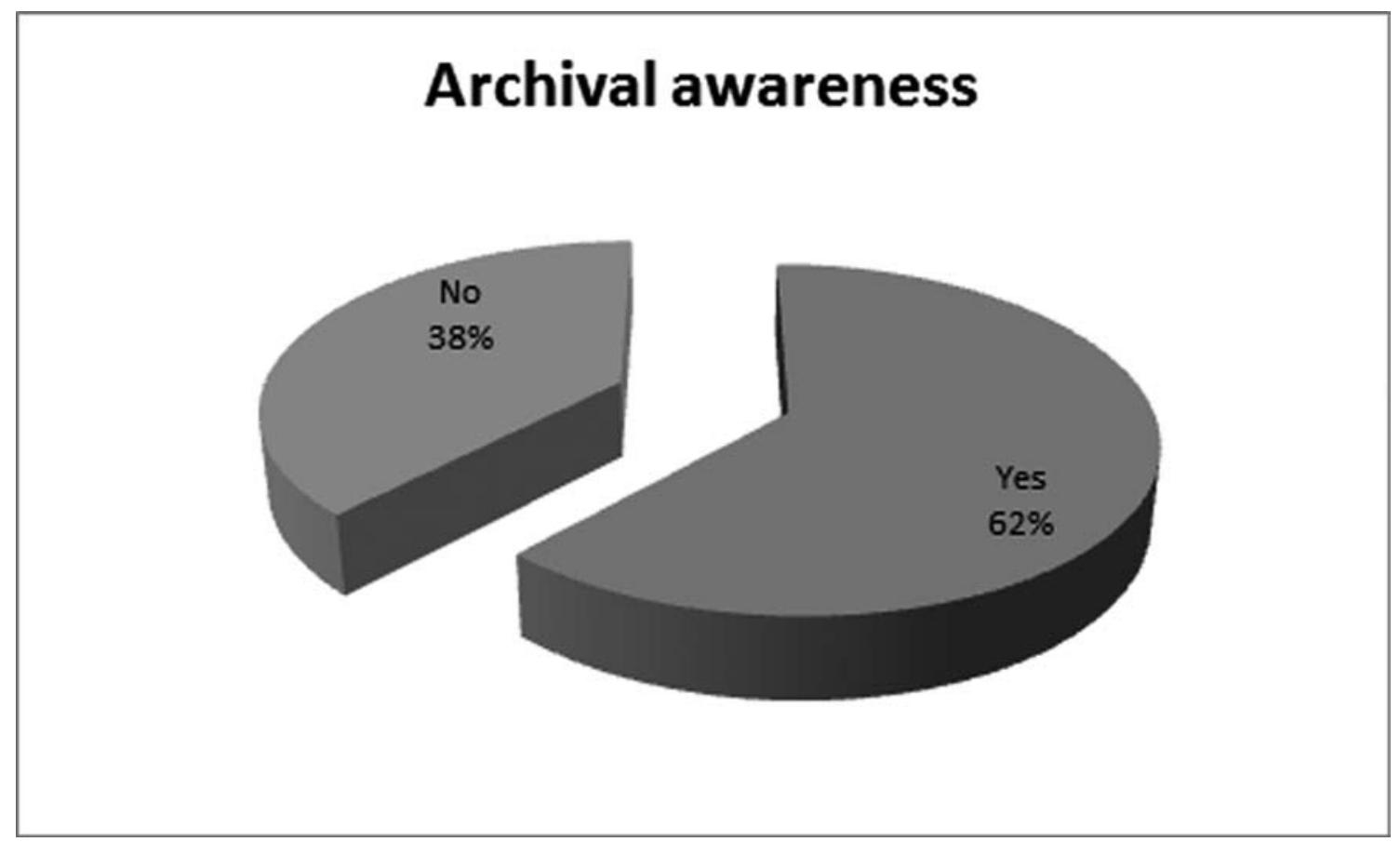

Image 2: Archival awareness

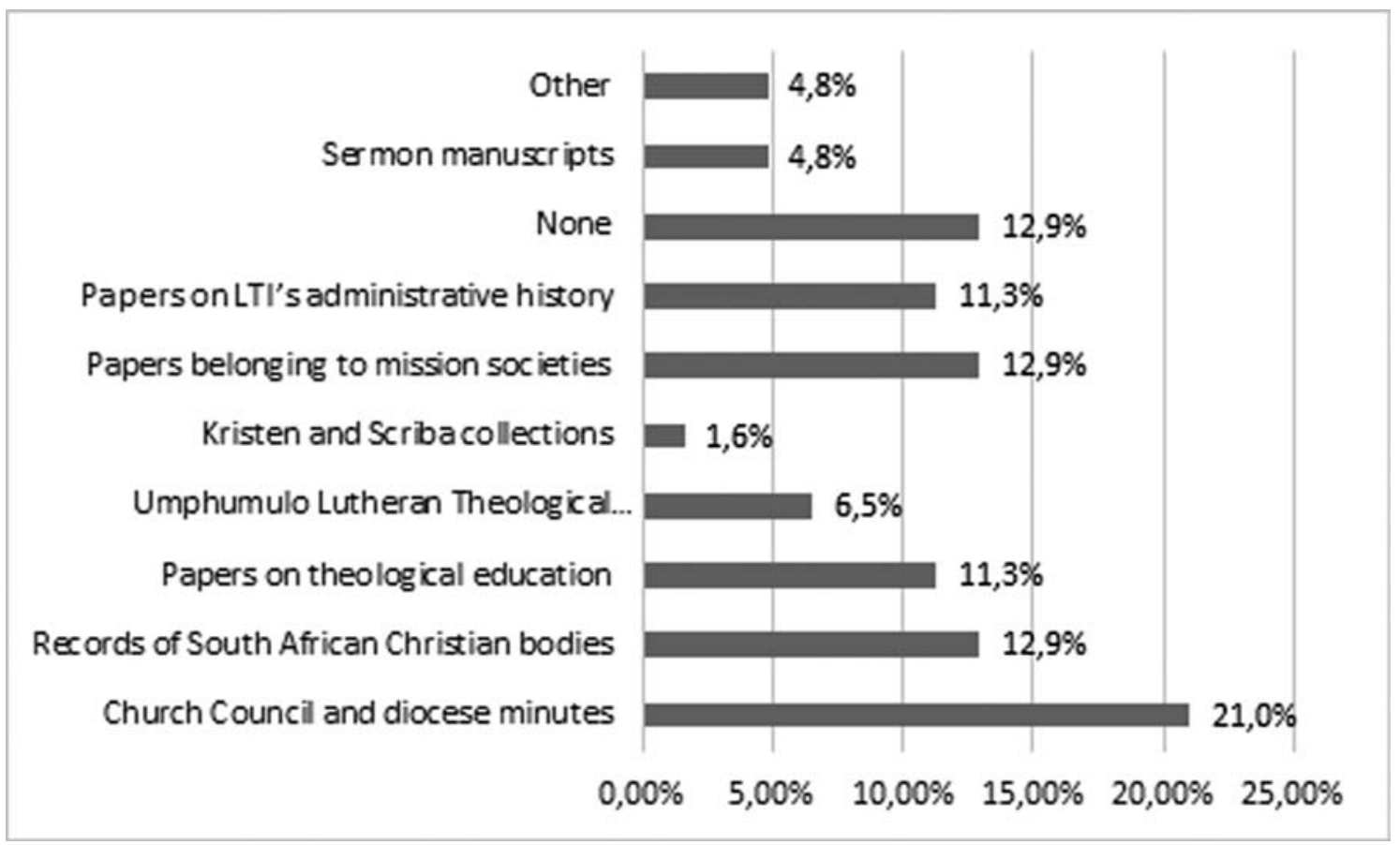

Image 3: Material familiar with users

Determine awareness about the existence of an LTI Archives brochure in the library

Publications in the form of brochures provide a medium of communicating with users of the archives. Jeremy et al (2008) noted that the brochure is an important means of advertising and they recommended that it is useful to have it available in many places where people can pick it up. However, in the LTI library, an archives brochure is filed with library guides at the front desk and users were thus asked whether they were aware of its existence. Figure 5 shows that 17 (59\%) of users compared to $12(41 \%)$ were aware of the LTI brochure in the library. 


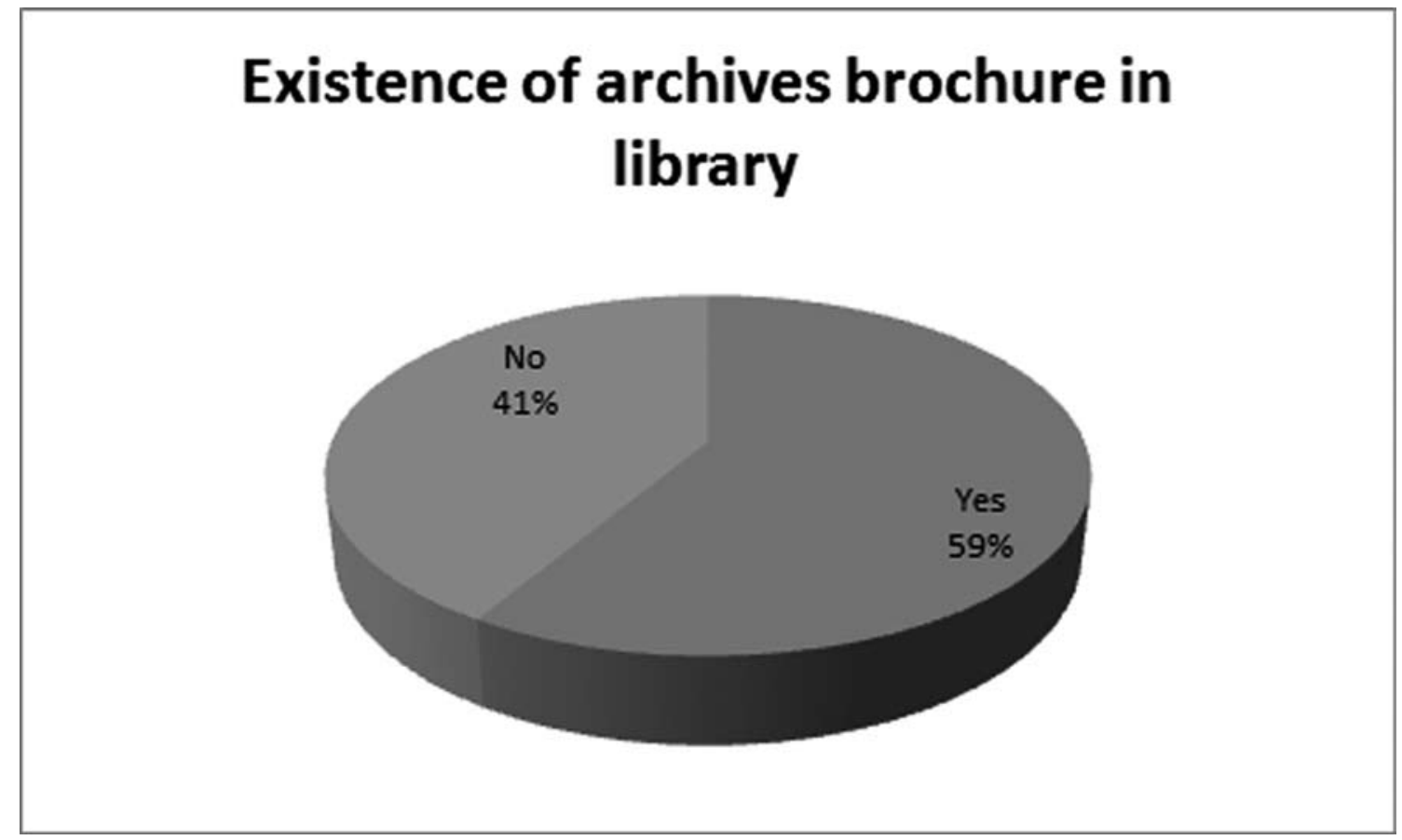

Image 4: LTI Archives brochure archives

Identify popular strategies recommended by users that the library should adopt to raise the profile of

A host of mechanisms are available in attempts to reach out to the community on the existence of archives. Figure 6 shows that exhibitions (19.2\%), Open day on archives (14.4\%), guided tours $(13.5 \%)$ and friends of the archives $(10.6 \%)$ were some of the popular strategies that users recommended in efforts to raise awareness about archives.

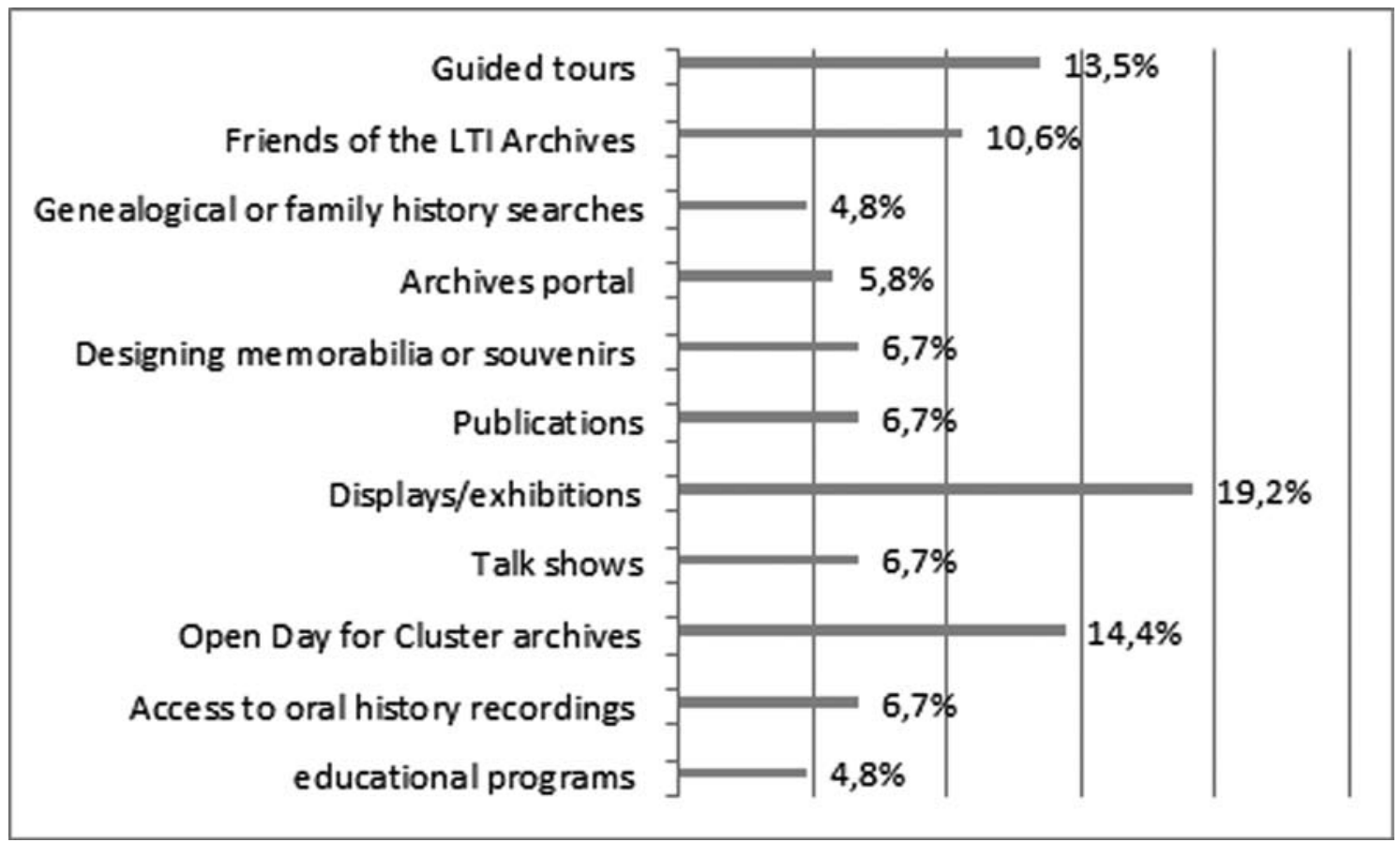

Image 5: Recommended advocacy strategies by users 


\section{Discussion of results}

At the LTI Archives, the recommended public programming activities by users were publications, exhibitions, an Open day on Archives, guided tours and friends of the archives. Publications in the form of brochures remain one of the most effective mechanisms of raising the profile of an archive. Roe $(1988, p .225)$ noted that archives use publications to provide impetus and information about their resources. Pederson (2008) concurred and noted that publications are valuable tools for educating the community about the archives, its holdings and services. However, Pederson (2008) also noted that publishing commitments require considerable investment of resources. Much time and energy, usually of senior staff, go into their preparation, and production costs can be substantial, particularly if multiple colours, illustrations and traditional printing methods are used (Pederson, 2008). The findings revealed that one publication the bulk of users were aware of was the LTI brochure in the library because it is easily accessible. Items of information that are included in this brochure are: street address, website address, contact details, opening hours, nature of the collection, types of records held, and special conditions.

Exhibitions will always be popular with users because they are eye-catching and as noted by Pederson (2008) they provide a vehicle for the archives to show off its collections. More importantly as noted by Bradsher and Ritzenthaler $(1988, p$. 228) archival exhibits are mounted to interest, inform, stimulate, entertain and educate viewers. The downside of exhibitions notwithstanding the fact that they are naturally short-term are the attendant challenges with regards to the conservation and security of material. It was in this light that Pederson $(2008, p .438)$ remarked that while public interest, enthusiasm and contact with original sources is to be encouraged, it should however not be at the peril of records. Nonetheless, having an open day on archives is significant in that it enables the user to take pride in the collections and identify with the heritage as this makes the user feel special and have that sense of belonging. Guided tours in archives enable users to be familiar with their archives in terms of their housing and special stewardship needs. Stakeholders input calls for archivists to be activists in order to endear influential people to the cause of archives and this explains why users recommended the LTI Archives to establish a friends of the archives group.

\section{Conclusion}

Displays remain an integral aspect in showcasing the holdings of an archival repository and the International Archives Day in June every year should help in this endeavor. In view of the fact that there was so much enthusiasm from users generated by the displays in 2014, much needs to be done in this regard to endear the Lutheran community to their archives. Consequently, the rich photographic heritage of the institution's corporate history in digital form should be used to create an interactive exhibit in an effort to raise awareness about archives. Using digital instead of analogue photographic copies as was the case in 2014, will help in safeguarding their useable lifespan with regards to handling issues. In addition having an Open Day on archives for the theological cluster as recommended by users will also help in this cause. This Open Day could be done biennially on a rotational basis by the theological institutions affiliated to the cluster just like the popular Cluster Sports Day which promotes recreational collegiality in true ecumenical spirit.

\section{References}

Blais, G. and Ennes, D. (1990-91). From paper archives to people archives: public programming in the management of archives. Archivaria, 31, pp. 101-113.

Bradsher, J. G. and Ritzenthaler, M. L. (1988). Archival exhibits. In: Bradsher, J. G. (ed). Managing archives and archival institutions, pp. 228-240. London: Mansell Publishing Limited.

Duff, W. M. and Cherry, J. M. (2008). Archival orientation for undergraduate students: an exploratory study of impact. American Archivist 71, (Fall/Winter), pp. 499-522.

Ericson, T. (1990-91). Preoccupied with our own gardens: outreach and archivists. Archivaria 31, pp. 114122.

Freeman, E. (1984). Education programs: outreach as an administrative function. In: Daniels, M. F. And Walch, T. (eds), A modern archives reader: basic readings on archival theory and practice, pp. 289-296. Washington, D. C.: National Archives and Records Service. 
Francis GARABA: Lutheran Theological Education in an Ecumenical and Multicultural Setting: Public Use of Archives and Perceptions at the Lutheran Theological Institution (LTI) Library..., 215-224

Garaba, F. and Zaverdinos, A. (2014). The Evangelical-Lutheran Church in South Africa: an introduction to its archival resources held at the Lutheran Theological Institute (LTI) Library, and the challenges facing this archive (Part One). Missionalia: Southern African Journal of missiology, 42, (1-2), pp. 5-28.

Harris, V. (2000). Exploring archives: an introduction to archival ideas and practice in South Africa. Pretoria: National Archives of South Africa.

Hunter, G. S. (2003). Developing and maintaining practical archives: a how-to-do-it manual. New York: NealSchuman Publishers, Inc.

International Archives Day. (2014). WordPress Theme. Available at:

http://www.internationalarchivesday. org/wordpress/ (accessed on 20.09.2014).

Jeremy, J., Woodley, E. and Lupke, L. (2008). Access and reference services. In: Bettington, J., Eberhard, K., Loo, R. and Smith, C. (eds.), Keeping archives, pp. 351-378. $3^{\text {rd }}$ ed. Canberra, ACT, Australia: Australian Society of Archivists, Inc.

Millar, L. A. 2010. Archives: principles and practices. London: Facet Publishing.

Mnjama, N. (2009). Archival programming in the digital era: the challenge for ESARBICA archivists. Paper presented at the XX Bi-Annual East and Southern Africa Regional Branch of the International Council on Archives (ESARBICA) General Conference on "Documentary Heritage Management in the Digital Age: Beauty and the Beast", Namibia, National Archives of Namibia (Windhoek), 1-3 July 2009.

Ngoepe, M. and Ngulube, P. (2011). Assessing the extent to which the National Archives and Records Service of South Africa has fulfilled its mandate of taking archives to the people. Innovation: journal of appropriate librarianship and information work in Southern Africa, 42, pp. 3-22.

Ngulube, P. (1999). The marketing of archival services and products in east and southern Africa: opportunities for survival in the next millennium. ESARBICA journal: journal of the East and Southern Africa Regional Branch of the International Council on Archives, 18, pp. 19-25.

Pederson, A. (1983). User education and public relations. In: Ellis, J. (ed). Keeping archives, pp. 306-349. $2^{\text {nd }}$ ed. Pourt Melbourne, Victoria: D W Thorpe.

Pederson, A. (2008). Advocacy and outreach. In: Betttington, J., Eberhard, K., Loo, R. and Smith, C. (eds.), Keeping archives, pp. 435-474. $3^{\text {rd }}$ ed. Canberra, ACT, Australia: Australian Society of Archivists, Inc.

Roe, K. D. (1988). Public programs. In: Bradsher, J. G. (ed). Managing archival institutions, pp. 218-227. London: Mansell Publishing Limited.

Theimer, K. (2014). The role of archives in a digital society: now is what matters. Archivaria, 78, pp. 145147.

Van Rooyen, K.M. (1996). A performance evaluation of the Pietermaritzburg Cluster of Theological Libraries (PCTL) in order to determine whether it meets the demands of its users. Master of Information Studies thesis. Pietermaritzburg: University of Natal. School of Human and Social Studies, Information Studies Programme,

\section{SUMMARY}

This paper highlights the role of exhibitions and publications as important mechanisms in raising the profile of archives as evidenced by a study conducted at the LTI Archives in 2014. Empirical data collected from this research reveals that patrons at the LTI Archives preferred displays, an Open Day on Archives, Friends of Archives Group and publications in an effort to showcase the holdings of the repository at the institution. The study revealed also that church minutes were the most frequently consulted and that these were to be prioritized for digitization to safeguard them from degradation due to frequent handling. The study also acknowledged the challenges that the preferred strategies as recommended by patrons in raising awareness about archives would bring namely cost in terms of publications and exposure of material to agents of deterioration during these displays. One important recommendation is that the institution's corporate history in digital form should be used in future displays as this will help in prolonging their useable life in view of handling issues.

Typology: 1.01 Original Scientific Article

Submitting date: 29.01 .2016

Acceptance date: 20.02 .2016 
Francis GARABA: Lutheran Theological Education in an Ecumenical and Multicultural Setting: Public Use of Archives and Perceptions at the Lutheran Theological Institution (LTI) Library..., 215-224

\section{Appendix 1: International Archives Day photographs}

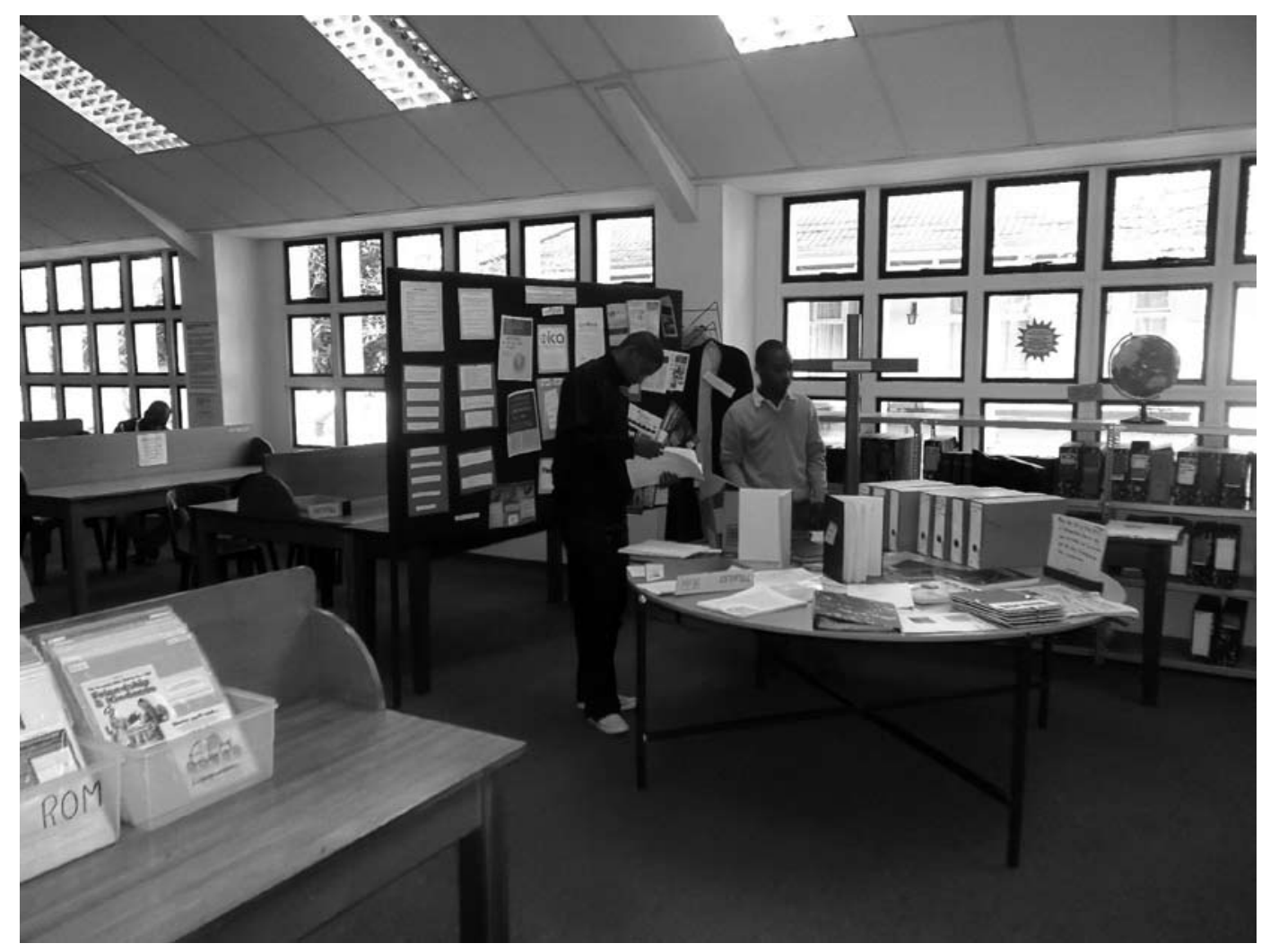

Image 6: Viewers at the ICA Archives day 2014: LTI Library

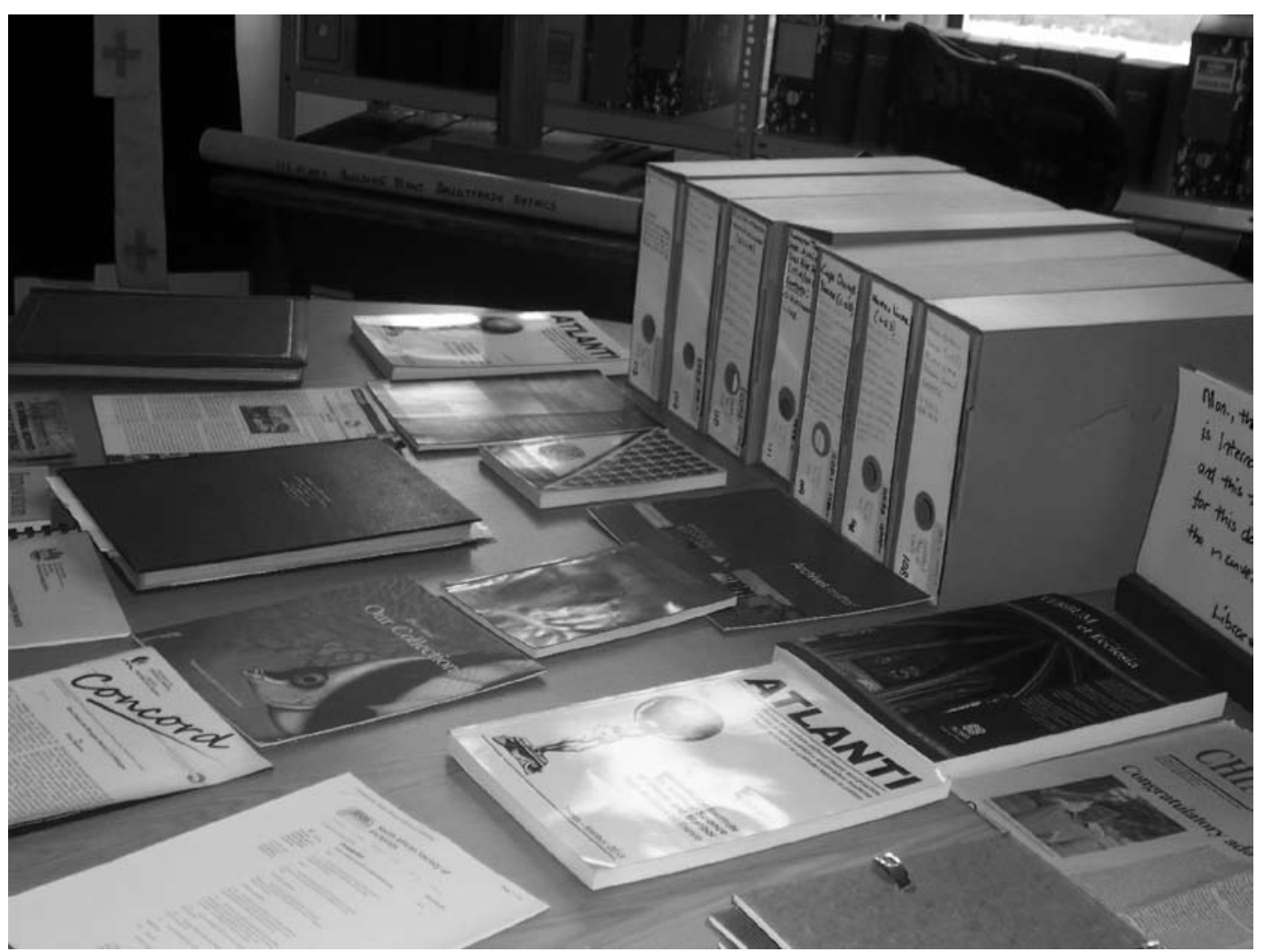

Image 7: Archivalia \& memorabilia on display: ICA Archives Day 2014 at the LTI Library 
Francis GARABA: Lutheran Theological Education in an Ecumenical and Multicultural Setting: Public Use of Archives and Perceptions at the Lutheran Theological Institution (LTI) Library..., 215-224

\section{Appendix 2: Religious Archives Prayer}

Rescuing the Memory of our Peoples, Core Group Teleconference opening prayer

O God our Father and Creator, You have left your image on every creature.

Your footprints are on all the pathways of the universe.

Your fingerprints adorn and embellish every being.

You have inspired all holy men and women, sages, gurus, prophets, bodhisattvas, jinas, tirthankaras, suffis and saints to leave a record of their perception of you in meditation, dream, and vision, their experience of you in prayer and contemplation, in renunciation and simplicity of life, both in creation and in history.

Our spiritual and cultural ancestors have left behind monuments, carvings, paintings in caves and frescoes, on stones, tablets, in epics and stories, in oral and written traditions, and they serve as signposts of your hidden presence in creation and historical revelation.

You inspired the disciples of your Son Jesus Christ to treasure up for all ages to come his saving image, precepts and words in the scriptures.

These agents of the mission of your Son always sought to leave behind a record of their activities in extending your kingdom on earth as lesson for posterity.

May we gather up the scattered fragments of the history of their heroism and holiness, their love for all the peoples of the world, and the history of their service to the Churches.

May we cherish and preserve them.

May we learn from their experience.

May we be inspired by their zeal.

Inspire, illumine and guide us as missionaries, interested in preserving and promoting all that reminds us of your saving presence and work in the world, especially of the mission of your Son Jesus Christ.

May your blessings accompany our enterprise.

May this prayer rise from our hearts to your throne in the name of Jesus Christ your Son and our Saviour,

and the Lord of all history,

Sebastian Karotemprel, SDB

Amen.

Source: Rescuing the Memory of our Peoples, Core Group Teleconference, 12 March, 2001. 